Н.С. Урум, Р.М. Гімпель, В.В. Ліганенко, О.І. Рященко, О.С. Бабере

Державний університет інфраструктури та технологій, Ізмаїл

\title{
АНАЛІЗ ДОСЛІДЖЕНЬ ЩОДО ВИКОРИСТАННЯ АЛЬТЕРНАТИВНИХ ВИДІВ ПАЛИВА ДЛЯ ГАЗОТУРБІННИХ ЕНЕРГЕТИЧНИХ УСТАНОВОК НА МОРСЬКИХ СУДНАХ
}

\begin{abstract}
На даний час морська транспортна галузь пережсиває ряд проблем, пов'язаних з використанням традиційного палива для морських суден, наприклад, дизельного палива. Так, дизельне паливо вважається основним компонентом, що викликає як екологічні, так і економічні проблеми, особливо в зв'язку з постійним зростанням вартості палива. Метою статті є вибір найбільш ефективних з екологічної та економічної точок зору видів палива для морських суден за результатами аналізу досліджень з використання альтернативних видів палива. Зокрема, в даній статті досліджується можливість використання природного газу $i$ водню в якості альтернативного палива замість дизельного палива для газотурбінних енергетичних установок. Розглянуто вплив альтернативного палива на термодинамічні характеристики газотурбінних енергетичних установок. Результати показали, що природний газ $і$ водень можуть бути успішно використані в якості альтернативи для заміни використовуваного в даний час дизельного палива в морських газотурбінних енергетичних установках.
\end{abstract}

Ключові слова: альтернативне паливо, дизельне паливо, натуральний газ, водень, газотурбінна енергетична установка, морське судно.

\section{Вступ}

Постановка проблеми. На даний час морській транспорт продовжує відігравати ключову роль у світовій торгівлі, забезпечуючи перевезення більшої частини міжнародних товарів. Зокрема, більше $90 \%$ світової торгівлі здійснюється саме через міжнародне судноплавство.

Збільшення товарообігу з використанням морського транспорту, в свою чергу, призводить до збільшення споживання палива морськими судами. Ця тенденція щодо збільшення споживання палива морськими суднами скоріше за все збережеться і в наступні роки. Іншою особливістю $\epsilon$ постійне зростання цін на паливо, що призводить до ситуації, коли вартість палива стає ще більш значною для загальних експлуатаційних витрат судна. Третьою особливістю є значний внесок морських суден у глобальні викиди в атмосферу і відповідно в забруднення морського повітря при використанні традиційних видів палива.

Одним 3 напрямків вирішення перерахованих проблем $є$ використання альтернативного палива замість традиційного.

Метою статті $\epsilon$ вибір найбільш ефективних 3 екологічної та економічної точок зору видів палива для морських суден за результатами аналізу досліджень щодо використання альтернативних видів палива для газотурбінних енергетичних суднових установок.

Аналіз останніх джерел і публікацій. У робо-
Tax Morsy El Gohary M., Sadek I.S., Kjell M.S., Veldhuis I.J.S., Richardson R.N., Ston H.B.J. розглянуті питання використання альтернативного суднового палива для газотурбінних електростанцій на борту суден [1; 3; 5-6]. В роботі Astbury G.R. проведено огляд властивостей і небезпек деяких альтернативних видів палива [2]. В роботі Banawan A.A., Morsy El Gohary M., Sadek I.S. розглянуті екологічні та економічні вигоди від переходу з суднового дизельного палива на газове паливо для малопотужних пасажирських суден великої потужності [3]. У роботі [4] досліджені питання використання природного газу в якості палива для суден. В роботі Welaya Y.A., Morsy El Gohary M., Ammar N.R. проведено порівняння паливних елементів та інших альтернатив при виробленні судновий електроенергії [7]. У роботах Болдирєва О.Н., Слободянюк Л.І., Полякова В.І. розглянуті принципи функціонування суднових енергетичних установок [8-12].

\section{Виклад основного матеріалу}

Основні альтернативні види палива для морських суден можуть бути представлені в двох формах:

1) у вигляді рідкого палива (наприклад, етанол, метанол, біорідинне паливо, біодизель і т. д.);

2) газоподібне паливо (наприклад, водень, природний газ і т. д.).

Незважаючи на те, що всі ці види палива більш екологічні, ніж традиційне паливо, деякі з них, як і раніше, важко широко застосовувати на борту суден через низький вміст енергії (наприклад, метанол й 
етанол). Дослідження показали, що саме водень і природний газ можна розглядати як альтернативу застосування на борту суден, особливо з точки зору економічних і екологічних проблем [1; 3; 5-6].

Найбільш чутливим до виду палива на морському судні є газотурбінні енергетичні установки, що пов'язано з відмінністю процесу згоряння палива. Газотурбінна енергетична установка - комплекс технічних засобів, призначений для перетворення кінетичної і теплової енергії гарячого газу в механічну енергію обертання ротора [8-9].

Надалі в роботі проаналізовані більш детально:

- особливості використання альтернативних видів палива (зокрема, природного газу і водню) на борту морського судна;

- результати досліджень технічних показників за можливістю використання альтернативних видів палива в якості основного палива для газотурбінних енергетичних установок.

Природний газ - суміш вуглеводнів, переважно метану, $з$ невеликими домішками інших газів, що видобувається 3 осадових гірських порід Землі. Природний газ - важливе джерело енергії для зменшення забруднення і підтримки чистого навколишнього середовища. Основними продуктами згоряння природного газу є вуглекислий газ і водяний пар. У табл. 1 представлено порівняння вугілля, дизельного палива і природного газу з точки зору викидів [1; 3].

Таблиця 1

Рівні викидів палива г/кВт год

\begin{tabular}{|l|c|c|c|}
\hline \multicolumn{1}{|c|}{ Забруднювач } & Вугілля & Дизельне паливо & Природний газ \\
\hline Вуглекислий газ & 322,14 & 254 & 181,2 \\
\hline $\begin{array}{l}\text { Монооксид } \\
\text { вуглецю }\end{array}$ & 0,322 & 0,051 & 0,618 \\
\hline Оксиди азоту & 0,707 & 0,693 & 0,142 \\
\hline Діоксид сірки & 4,137 & 1,791 & 0,001 \\
\hline
\end{tabular}

Джерело: розроблено авторами.

На борту суден природний газ знаходиться в трьох формах: в газовій, рідкій (зріджений природний газ (ЗПГ)); у формі стисненого газу.

Останнім часом ряд компаній вперше застосували ЗПГ в якості палива, особливо для суден, що виконують регулярні каботажні або короткі морські перевезення. Для використання ЗПГ в якості палива на борту морських суден необхідне рішення таких завдань:

1) зберігання ЗПГ;

2) проведення трубопроводів для суден, що працюють на ЗПГ;

3) удосконалення паливної системи ЗПГ.

ЗПГ зберігається в якості палива на борту суден в циліндричному криогенному резервуарі, який виготовлений зі спеціальних армованих пластиків. Для суден, що працюють на ЗПГ, газопроводи, як правило, не повинні проходити через житлові приміщення, службові приміщення або приміщення управління. Будь-яка газова труба, що проходить через замкнутий простір на судні за межами машинного відділення, повинна бути розташована всередині подвійної труби або повітропроводу з механічною вентиляцією. Розмір повітропроводу повинен бути таким, щоб витримувати тиск, що створюється при розриві труби. Паливна система ЗПГ в основному складається з бака ЗПГ, клапанів, з'єднань і випарника. Кожен резервуар разом 3 випарником, а також всі клапани і з'єднання резервуара розташовані в контейнері з нержавіючої сталі. Це забезпечує вторинний бар'єр у разі витоку ЗПГ. Контейнер має теплоізоляцію по відношенню до суднової сталі, щоб запобігти охолодженню суднової сталі нормальної якості. Він також має протипожежну ізоляцію i обладнаний системою вентиляції, виявлення газів i сигналізацією трюмних колодязів.

Водень $є$ найпоширенішим елементом на Землі, але в звичайних умовах він не зустрічається ні у вигляді водню, ні у вигляді газоподібного водню. Велика частина водню Землі пов'язана в хімічних сполуках. Отже, водень для масштабного використання слід витягати з таких джерел, як вода, вугілля, природний газ або рослинний матеріал $[1 ; 3 ; 5-6]$. Для використання водню в якості палива на борту морських суден необхідне вирішити питання зберігання водню на борту судна.

Найбільший потенціал для отримання чистого повітря з вихлопних газів може бути отриманий при використанні водню як палива, особливо в двигунах внутрішнього згоряння (ДВЗ). Коли водень спалюється в камері згоряння 3 повітрям, в результаті утворюється водяна пара плюс сліди оксидів азоту, отримані через вміст азоту в повітрі. Велика кількість досліджень показала можливість використання водню як палива для суднових енергетичних установок [1-7]. При цьому було встановлено, що вони потребують певної модифікації в разі використання водню в ДВ3 з точки зору конструкції двигуна. 3берігання водню на борту суден повинно бути в рідкій формі, оскільки воно забезпечує найбільшу кількість водню, що зберігається в мінімальному обсязі.

В роботі [1] запропоновано проведення оцінки впливу властивостей альтернативних видів палива на продуктивність газової турбіни за такими показ- 
никами (на основі моделювання турбіни GE LM2500 (рис. 1)):

1) ефективність робочого циклу газотурбінного двигуна $\mu_{\text {cycle }}$ значення якого дорівнює

$$
\mu_{\text {cycle }}=\frac{W_{P T}}{C V_{\text {air }}},
$$

де $W_{P T}$ - питома робота силової турбіни,

$C V_{\text {air }}$ - зміст енергії в паливі;

2) питома витрата палива $s f c$, значення якої визначається як

$$
s f c=\frac{m_{f}}{P_{\text {out }}},
$$

де $m_{f}$ - витрати палива,

$P_{\text {out }}$ - вихідна потужність;

3) пікова температура:

$$
\varepsilon=\frac{T_{\text {burn }}}{T_{\text {air }}}
$$

де $T_{\text {burn }}$ - температура згоряння;

$T_{\text {air }}$ - температура повітря;

4) коефіцієнт роботи:

$$
W R=\frac{W_{P T}}{W_{C T}},
$$

де $W_{P T}$ - робота силової турбіни, що розвивається всередині турбіни,

$$
W_{C T} \text { - загальна вироблена робота; }
$$

5) витрата повітря:

$$
m_{\text {air }}=\frac{P_{\text {out }}}{W_{P T}} ;
$$

6) витрата вихлопних газів:

$$
m_{\text {ex }}=m_{\text {air }}+m_{f} .
$$

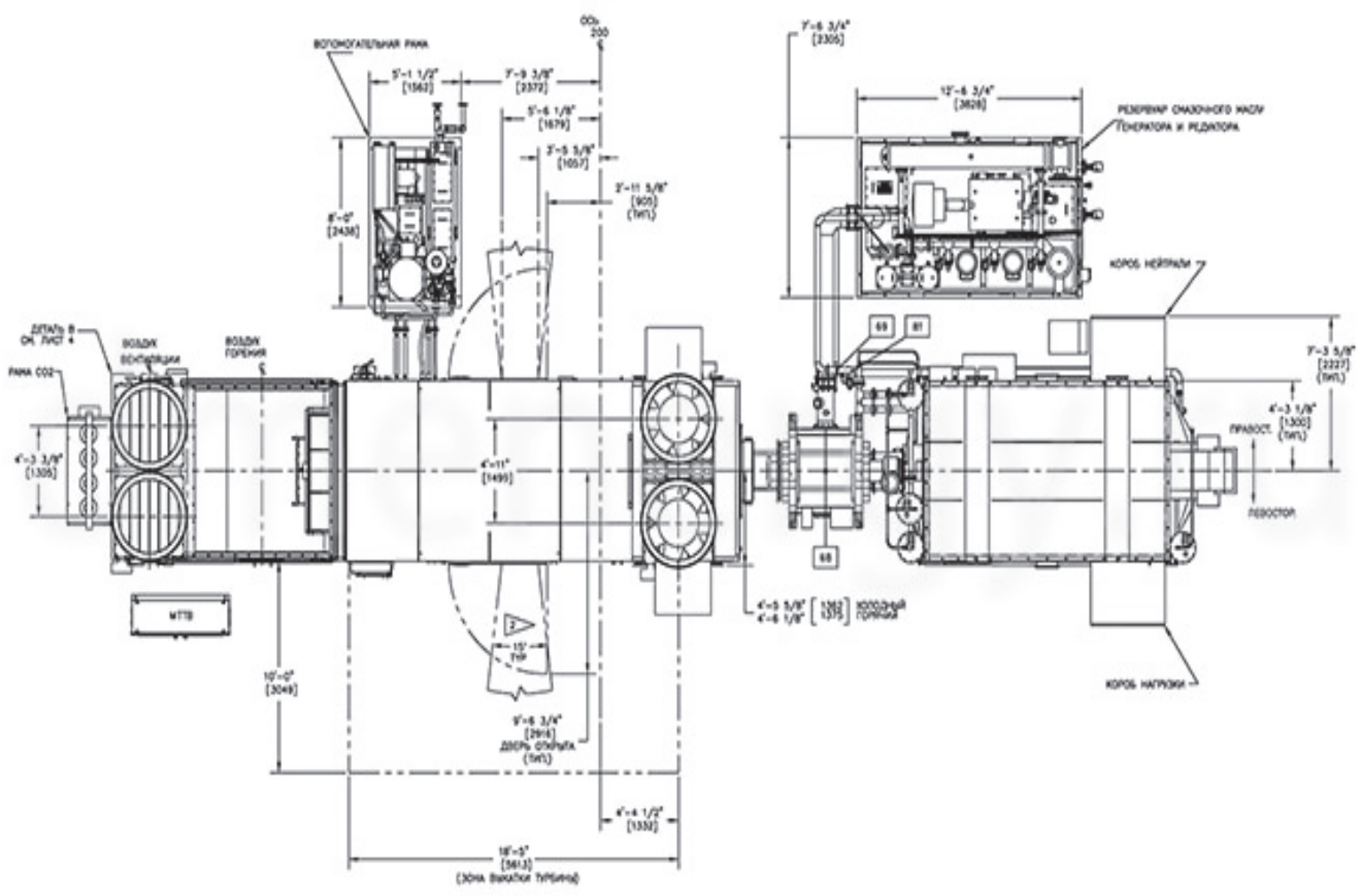

Рис. 1. Конструкція турбіни GE LM2500 Джерело: [1].

Основні результати дослідження ефективності використання класичного палива (дизельного пали- ва) і альтернативних видів (природного газу, водню) наведені в табл. 2 [1].

Таблиця 2

Основні результати дослідження для трьох видів палива

\begin{tabular}{|l|c|c|c|}
\hline $\begin{array}{c}\text { Показники оцінки впливу } \\
\text { властивостей видів палива } \\
\text { на продуктивність газової турбіни }\end{array}$ & $\begin{array}{c}\text { Дизельне } \\
\text { паливо }\end{array}$ & $\begin{array}{c}\text { Природний } \\
\text { газ }\end{array}$ & $\begin{array}{c}\text { Водневе } \\
\text { паливо }\end{array}$ \\
\hline Ефективність & 0,3798 & $0,3788(-0,26 \%)$ & $0,376(-1 \%)$ \\
\hline Питома витрата палива & 0,2169 & $0,1876(-13,5 \%)$ & $0,0792(-63,49 \%)$ \\
\hline
\end{tabular}


Закінчення табл. 2

\begin{tabular}{|l|c|c|c|}
\hline $\begin{array}{c}\text { Показники оцінки впливу } \\
\text { властивостей видів палива } \\
\text { на продуктивність газової турбіни }\end{array}$ & $\begin{array}{c}\text { Дизельне } \\
\text { паливо }\end{array}$ & $\begin{array}{c}\text { Природний } \\
\text { газ }\end{array}$ & $\begin{array}{c}\text { Водневе } \\
\text { паливо }\end{array}$ \\
\hline Максимум температури & 1485 & $1474(-0,74 \%)$ & $1444(-2,76 \%)$ \\
\hline Коефіцієнт роботи & 0,443 & $0,4388(-0,97 \%)$ & $0,4269(-3,72 \%)$ \\
\hline Витрата повітря & 70,84 & $72,32(+2,09 \%)$ & $76,71(+8,29 \%)$ \\
\hline Витрата вихлопних газів & 72,35 & $73,62(+1,76 \%)$ & $77,26(+6,79 \%)$ \\
\hline
\end{tabular}

Джерело: розроблено авторами.

\section{Висновки}

Аналіз результатів досліджень дозволяє зробити такі висновки:

1) обидва альтернативних газових палива дають більш низький коефіцієнт корисної дії, ніж дизельне паливо, при тій же вихідній потужності;

2) більш висока теплотворна здатність як природного газу, так і водню, у порівнянні з дизельним паливом знижує кількість палива, використовуваного для отримання тієї ж теплової потужності;

3) отримані пікові температури для природного газу і водню нижче, ніж для дизельного палива;

4) низький коефіцієнт корисної дії альтернати- вних видів палива визначає і їх низький коефіцієнт роботи, у порівнянні з дизельним;

5) після збільшення витрати повітря для природного газу і водню, вихлоп також збільшується, але на менший відсоток у порівнянні $з$ дизельним варіантом, це менше збільшення пов'язане з більш низькими витратами палива для обох видів газового палива. У загальному сенсі можна зробити висновок, що природний газ і водень можуть бути успішно використані в якості альтернативи для заміни використовуваного в даний час дизельного палива в морських газотурбінних енергетичних установках.

\section{Список літератури}

1. Morsy El Gohary M., Sadek I. S. Utilization of alternative marine fuels for gasturbine powerplant on boardships. International Journal of Naval Architecture and Ocean Engineering. 2013. No. 5(1). P. 21-32.

2. Astbury G. R. Areview of the properties and hazards of some alternative fuels. Process Safety and Environment Protection Journal. 2008. No. 86(6). P. 397-414.

3. Banawan A. A., Morsy El Gohary M., Sadek I. S. Environmental and economical benefits of changing from marinedieseloil to natural-gasfuel for short-voyage high-power passenger ships. Journal of Engineering for the Maritime Environment. 2010. No. 224(2). P. 103-113.

4. Kjell M. S. Use of natural gas as fuel for ships. Elidesvik offshore ASA, work shop on marine technology-panel 1. web site. URL: http://www.docstoc.com/docs/19963852/Use-of-Natural-Gas-as-Fuel-for-Ships (accessed 27.05.2021).

5. Morsy El Gohary M. The future of natural gas as a fuel in marine gasturbine for LNG carriers. Journal of Engineering for the Maritime Environment. 2012. No. 226(4). P. 371-377.

6. Veldhuis I. J. S., Richardson R. N., Ston H. B. J. Hydrogen fuel in a marine environment. International Journal of Hydrogen Energy. 2007. No. 32(13). P. 2553-2566.

7. Welaya Y. A., Morsy El Gohary M., Ammar N. R. A comparison between fuel cells and other alternatives for marine electric power generation. International Journal of Naval Architecture and Ocean Engineering. 2011. No. 3(2). P. 141-149.

8. Болдырев О. Н. Судовые энергетические установки. Часть І. Дизельные и газотурбинные установки : учеб. пособие. Северодвинск : Севмашвтуз, 2003. $171 \mathrm{c}$

9. Слободянюк Л. И., Поляков В. И. Судовые паровые и газовые турбины и их эксплуатация. Ленинград : Судостроение, 1983.360 с.

10. Основні елементи енергетичних газотурбінних установок та їх призначення. веб-сайт. URL: http://energetika.in.ua/ua/books/book-3/part-1/section-3/3-7 (дата звернення 27.05.2021).

11. Українські газотурбіни. веб-сайт. URL: https://defence-ua.com/people_and_company/ukrajinski_gazoturbini304.html (дата звернення 27.05.2021).

12. Чверть газотурбінного світового флоту обирають газотурбінні двигуни. веб-сайт. URL: https://shipbuilding.mk.ua/?p=2765 (дата звернення 27.05.2021).

Надійшла до редколегії 28.07.2021

Схвалена до друку 14.09.2021

\section{Відомості про авторів:}

Урум Наталія Степанівна

кандидат педагогічних наук

доцент Дунайського інституту водного транспорту

Державного університету інфраструктури та технологій, Ізмаїл, Україна

https://orcid.org/0000-0003-2493-9314

\section{Information about the authors:}

\section{Natalia Urum}

Candidate of Pedagogical Sciences

Associate Professor of Danube Institute of Water Transport

State University of Infrastructure and Technologies

Izmail, Ukraine

https://orcid.org/0000-0003-2493-9314 
Гімпель Роман Михайлович кандидат технічних наук доцент доцент Дунайського інституту водного транспорту Державного університету інфраструктури та технологій, Ізмаїл, Україна

https://orcid.org/0000-0003-0546-6654

\section{Ліганенко Віталій Валерійович}

старший викладач Дунайського інституту водного транспорту Державного університету інфраструктури та технологій, Ізмаїл, Україна https://orcid.org/0000-0002-6523-4137

\section{Рященко Оксана Іванівна} старший викладач Дунайського інституту водного транспорту Державного університету інфраструктури та технологій,

Ізмаїл, Україна

https://orcid.org/ 0000-0002-9242-0752

\section{Бабере Оксана Сергї̈вна}

старший викладач Дунайського інституту водного транспорту Державного університету інфраструктури та технологій, Ізмаїл, Україна https://orcid.org/ 0000-0002-8711-8495

\section{Roman Gimpel}

Candidate of Technical Sciences Associate Professor

Senior Lecturer of Danube Institute of Water Transport State University of Infrastructure and Technologies Izmail, Ukraine

https://orcid.org/0000-0003-0546-6654

\section{Vitalii Liganenko}

Senior Instructor of Danube Institute of Water Transport State University of Infrastructure and Technologies Izmail, Ukraine https://orcid.org/0000-0002-6523-4137

\author{
Oksana Ryashchenko \\ Senior Instructor of Danube Institute \\ of Water Transport State University \\ of Infrastructure and Technologies \\ Izmail, Ukraine \\ https://orcid.org/ 0000-0002-9242-0752
}

Oksana Babere

Senior Instructor of Danube Institute of Water Transport State University of Infrastructure and Technologies Izmail, Ukraine https://orcid.org/ 0000-0002-8711-8495

\title{
АНАЛИЗ ИССЛЕДОВАНИЙ ПО ИСПОЛЬЗОВАНИЮ АЛЬТЕРНАТИВНЫХ ВИДОВ ТОПЛИВА ДЛЯ ГАЗОТУРБИННЫХ ЭНЕРГЕТИЧЕСКИХ УСТАНОВОК НА МОРСКИХ СУДАХ
}

\author{
Н.С. Урум, Р.М. Гимпель, В.В. Лиганенко, О.И. Рященко, О.С. Бабере
}

В настоящее время морская транспортная отрасль переживает ряд проблем, связанных с использованием традиционного топлива для морских судов, например, дизельного топлива. Так, дизельное топливо считается основныл компонентом. Однако оно вызывает как экологические, так и экономические проблемы, особенно в связи с постоянным ростом стоимости топлива. Цель статьи - выбор наиболее эффективных видов топлива для морских судов, который учитывает экологические и экономические аспекты. Основой такого выбора являются результаты анализа исследований по использованию альтернативных видов топлива. В частности, в данной статье исследуется возможность использования природного газа и водорода в качестве альтернативного топлива вместо дизельного топлива для газотурбинных энергетических установок. Рассмотрено влияние альтернативного топлива на термодинамические характеристики газотурбинных энергетических установок. Результаты показали, что природный газ и водород могут быть успешно использованы в качестве альтернативы для замены используемого в настоящее время дизельного топлива в морских газотурбинных энергетических установках.

Ключевые слова: альтернативное топливо, дизельное топливо, натуральный газ, водород, газотурбинная энергетическая установка, морское судно.

\section{ANALYSIS OF STUDIES ON THE USE OF ALTERNATIVE FUELS FOR GAS TURBINE POWER PLANTS ON SEA SHIPS}

\section{N. Urum, R. Gimpel, V. Liganenko, O. Ryashchenko, O. Babere}

The maritime transport industry is currently experiencing a number of challenges associated with the use of conventional marine fuels such as diesel. For example, diesel fuel is considered to be the main component causing both environmental and economic problems, especially due to the constant increase in the cost of fuel. The purpose of the article is to select the most environmentally and economically efficient types of fuel for marine vessels based on the analysis of studies on the use of alternative fuels for gas turbine power ship installations. In particular, this article explores the possibility of using natural gas and hydrogen as an alternative fuel instead of diesel fuel for gas turbine power plants. The influence of alternative fuel on the thermodynamic characteristics of gas turbine power plants is considered. The results have shown that natural gas and hydrogen can be successfully used as an alternative to replace the currently used diesel fuel in marine gas turbine power plants.

Keywords: alternative fuel, diesel fuel, natural gas, hydrogen, gas turbine power plant, sea vessel. 